\title{
Save the Gold Watch Receipt: An Analysis of the Gift Tax on Athlete Retirement Gifts
}

\author{
Dylan P. Williams and Patrick Tutka*
}

\begin{abstract}
The retirement of professional athletes is an emotional and complex decision for competitors who dedicate their lives to a particular sport. It is common for professional teams, leagues, and other athletes to celebrate the careers of stellar professional athletes with charitable gestures and gifts. However, these gifts can create a financial burden when one is required to pay the gift tax on the item's value. The purpose of this study is to detail the rules, history, and application of Internal Revenue Code (IRC) Section (§) 102, which could tax athletes who give and receive gifts. Athletes should be cautious when giving gifts, as amounts exceeding the annual and lifetime exclusion limits can trigger the gift tax, causing future complications for decedents with the estate tax. Teams should also explicitly state their lack of a detached and disinterested generosity when honoring an athlete, as the gifts provided are considered taxable compensation.
\end{abstract}

Keywords: gift tax, gifts, professional athlete, retirement

\section{Introduction}

Since 2014, the sporting world has seen the retirements of some of the most prolific athletes such as Derek Jeter, Jeff Gordon, Kobe Bryant, and Peyton Manning to name a few (Hanzus, 2016; Holmes, 2016; Matthews, 2014; Spencer, 2015). The retirement of these athletes can be seen as an emotional and complex decision for competitors who dedicate their lives to a particular sport (Brewer, 1993; Brewer, Van Raalte, \& Linder, 1993; Kerr \& Dacyshyn, 2000; Lally, 2007; Sparkes, 1998). As such, it is common for other athletes and the professional leagues they compete within to celebrate their respective careers. For example, many Major League Baseball (MLB) players and team executives provided Jeter with gifts throughout the 2014 regular season (his final season, as was announced prior to the season) to honor and praise his career such as framed jerseys, customized boots, golf clubs, wine, vacation packages, and a 16-foot custom-painted kayak (Brisbee, 2014; Celani, 2014; Rose, 2014). Similarly, Gordon received various presents from the different speedways he raced during the 2015 NASCAR season such as a custom Bandolero car, a custom poker table, bourbon, and Shetland

\footnotetext{
* Dylan P. Williams, PhD, CPA, is an assistant professor of sport management in the Department of Kinesiology at the University of Alabama; email: dpwilliams@ua.edu. Patrick Tutka, PhD, is an assistant professor of sport management in the College of Hospitality \& Tourism Management at Niagara University; email: ptutka@niagara.edu
} 
ponies (DeCola, 2016). While these events seem out of the ordinary, the act of providing gifts to individuals for their contributions to their employer or field are not uncommon. According to Laura (2013), the most conventional and traditional gesture that employers provided to employees to honor their career is a gold watch. However, the gifts provided for these charitable events appear to be quite large in value. For example, Zumwalt (2014) noted the gifts Jeter received were valued at approximately $\$ 33,000$, and would require a payment of $\$ 16,000$ in taxes for these gifts.

Additionally, in 2014, the New England Patriots won Super Bowl XLIX, and Tom Brady was named Most Valuable Player (MVP) (Patra, 2015). For his MVP honors, Brady was awarded a 2015 Chevy Colorado from the National Football League (NFL) (Schechter, 2015). Instead of taking receipt, Brady chose to gift the truck to undrafted rookie safety Malcolm Butler as a gift since Butler sealed the Patriots' victory with a game-winning interception in the game's final seconds (Sorokanich, 2015). Three years later, Brady planned to repeat this gesture by providing another truck awarded to him in Super Bowl LI to running back James White, who scored the game-winning touchdown in the Super Bowl to go to overtime (DaSilva, 2017). Unfortunately, the NFL announced it had ended the practice of bequeathing a vehicle to the Super Bowl MVP recipient in 2016. Regardless, any potential gift of value given to White from Brady may require Brady to pay federal income taxes on the gifts he generously donated.

While these scenarios are different, they both require the payment of a tax related to gifts either contributed or received. Generally, a donee, or person receiving a gift, is not subject to paying taxes when receiving a gift (Internal Revenue Service [IRS], 2016a). Instead, the gift tax is paid by the donor providing the gift. Yet, in a situation like Jeter's, the donee is required to pay taxes on the gifts received since the items given to Jeter appear to lack any detached and disinterested generosity due to their business ties (i.e., teams promoting Jeter's last season as a New York Yankee), making the gifts taxable. These scenarios create some confusion as to how the gift tax works and whether someone must pay taxes on gifts they receive throughout the year. The purpose of this analysis is to explain the gift tax rules in the context of athletes giving and receiving gifts. Specifically, this study analyzes the history of the gift tax and the current rules provided in Internal Revenue Code (IRC) §102 including the exemption rules and tax calculation. Finally, this study discusses the implications and filing procedures for athletes who are subject to the gift tax as well as implications regarding the estate tax.

\section{The Gift Tax}

The United States (U.S.) Federal Income Tax came to existence in 1913 when Congress passed the Revenue Act of 1913, instituting the first IRC (Kramer \& Previts, 2015). IRC $\S 1$ establishes the income of all individuals is subject to taxation regardless of its source. IRC §61(a) generally defines gross income to include "all income charges from whatever source derived" (para. 1). These sources include compensation for services such as commissions and fringe benefits; business income; gains on property sales; interest and dividends; 
rent and royalties; alimony and separate maintenance payments; annuities; pensions; and income received in respect of a descendent or from an estate or trust. However, IRC §102(a) allows an individual receiving tangible or intangible property as a gift to deduct the value of said item from his or her taxable income. Instead, the entity providing the present may be subject to taxation on the gift's value (IRC $§ 102)$.

According to Joulfaian (1998), the gift tax was first enacted in 1924 as an attempt to reduce estate and income tax avoidance. IRC \$2001 details an individual's estate is taxed when assets from the individual (e.g., money, property) are transferred to his or her decedents (either through a will or through intestacy) upon his or her death. This original gift tax penalized donors who attempted to dodge the estate tax by providing gifts worth over $\$ 500$ per donee annually and over $\$ 50,000$ in one's lifetime at the established top estate tax rate of $40 \%$ (Joint Committee on Taxation [JCT], 2015). Any gifts of property or charitable contributions made within the past five years were subject to the tax. Despite this rationale, Luckey (2003) detailed there was stiff opposition to the gift tax in the mid-1920s, leading to its removal in 1926. Although the original gift tax was repealed, the Supreme Court upheld the constitutionality of the gift tax in Bromley v. McCaughn (1929), arguing the tax was an "excise which need not be apportioned" (p. 136) and required only intrinsic uniformity to be constitutional.

By the 1930s, the U.S. Government possessed increased demand to finance various government projects due to the Great Depression but lacked the necessary supply in revenue to fund these projects (Joulfaian, 1998). Faced with this significant revenue shortage, Congress instituted the Revenue Act of 1932 to increase estate tax rates and reintroduce a federal gift tax (Gale \& Slemrod, 2001). This new gift tax would establish a tax rate at three-quarters of the estate tax rates, a lifetime exclusion at $\$ 50,000$, and an annual exclusion at $\$ 5,000$ per donee (Luckey, 2003). Furthermore, no tax was imposed on charitable donations. Over the next 40 years, the basic gift tax exemptions would be altered but the rates would stay at three-quarters of the estate tax rates. In 1976, the gift tax was unified with the estate tax, creating a single graduate rate of tax imposed on lifetime gifts and testamentary dispositions (Luckey, 2003). Since that time, Congress has continued crafting modifications to the gift tax such as reducing the overall rate from its maximum of $70 \%$, reducing the threshold of the highest estate tax rate from $\$ 5$ million to $\$ 1$ million, and providing an unlimited deduction for transfers to spouses (JCT, 2015).

\section{Gift Tax Rules}

As mentioned earlier, the gift tax is a tax imposed on an annual basis on all gratuitous transfers of property made during the life of a taxpayer. The IRS (2016a) defines a gift as "lifetime transfers of property from one person (the donor) to another person (the donee)" (p. 25). The IRS further clarifies a gift can be made to a donee with tangible or intangible property (including money), the use of property, and the right to receive income from property if the donor does not expect to receive something of at least equal value in return. Gifts also differ from prizes and awards earned either through a game of chance (i.e., gambling/ 
lotteries, raffles, radio/television contest, etc.) or meeting work guidelines (i.e., bonuses) (IRS, 2016b). IRC §74 states prizes and awards must be included in gross income unless the following occur:

1. The recipient was selected without any legal action on his part to enter the contest or proceeding;

2. The recipient is not required to render substantial future services as a condition to receiving the prize or award;

3. The prize or award is transferred by the payor to a governmental unit or organization described in [IRC $\$ 170$ (c) (i.e., charitable organizations)], pursuant to a designation made by the recipient. (IRC §74, para. 2)

Typically, gifts often occur between family and friends, but exchanges between business partners, employers and employees, and complete strangers can be considered gifts (Dietz, 2014). However, the relationship between the donor and donee is not immaterial, as gifts in a familial context are common and typically qualify for $\$ 102$ (Burke \& Friel, 2013). In comparison, gifts within a commercial or business setting are less likely to receive the same favorable treatment. IRC \$132(a) states an individual's gross income will not include certain fringe benefits that one may consider gifts an employer provides employees. For example, any property or service provided by an employer that would be deductible expense for the employee if he or she paid for the item, such as the business use of a vehicle or any type of job-related education and training, is considered a working condition fringe benefit (IRC §132(d)). In order for an item to qualify as a working condition fringe benefit, the item must relate to the employer's business, the employee would be entitled to a tax deduction if paid personally, and the business use was substantiated with records (IRS, 2014).

Similarly, any property or service an employer gives to an employee that possesses such low value in relation to the frequency given, making it unreasonable and impractical to account for the item, is known as a de minimis fringe benefit (IRC §132(e)). Some examples include occasional snacks and drinks for employees, occasional parties or group meals, occasional theater or sporting event tickets (not season tickets), and traditional birthday or holiday gifts with a low fair market value. In comparison, items like season tickets to sporting or theatrical events, membership in a private country club, use of employer-owned or leased facilities (e.g., apartment, boat), and cash and cash equivalents (e.g., gift certificates, gift cards) do not qualify as de minimis benefits no matter how small the value (IRS, 2014). While the IRS has provided guidance once regarding value thresholds (PLR 200108042, 2001), the laws do not specify any limits for a benefit to qualify as de minimis (IRS, 2014). Instead, the determination of de minimis benefits depends on the facts and circumstances surrounding the item.

According to Lanza (2014), the major exclusions available to taxpayers are the annual per donee and lifetime exclusions. The annual per donee exclusions states that a donor can provide donee(s) gifts that are valued up to an annual exclusion amount during the current year (Rev. Proc. 2016-55, 2016). Between 2014 and 2017, the annual per donee exclusion amount has been $\$ 14,000$. In other words, an individual can provide gifts up to $\$ 14,000$ to each person he or she 
desires before potentially having to pay the gift tax (Rev. Proc. 2016-55, 2016). Furthermore, should a donor exceed the annual per donee exclusion amount, he or she may not have to pay the gift tax if his or her lifetime gift threshold has not been exceeded (Rev. Proc. 2013-35, 2013). This justification means the donor will still be required to report the taxable gift on his or her annual tax return in order to maintain records of an individual's lifetime exclusion for the federal estate tax. For example, if an individual makes a gift of $\$ 1$ million during his or her lifetime, then he or she will only be able to omit the remainder of the lifetime exclusion from the estate tax. In 2016, the lifetime exclusion amount was $\$ 5.49$ million (Rev. Proc. 2016-55, 2016). Using this figure, an individual making a \$1 million gift will have to deduct $\$ 986,000$ ( $\$ 1$ million gift less $\$ 14,000$ annual per donee exclusion) from his or her lifetime exclusion amount, leaving \$4.504 million as an exemption for estate taxes.

Lanza (2014) argued the gift tax accounts for transfers of property that would otherwise reduce the estate and related tax liabilities at death. Thus, when an individual receives a gift, the donee is typically not required to pay taxes on the fair market value of the item according to $\$ 102$. Yet, if the item considered a gift was not given as a true gift (i.e., a reward, prize, or form of compensation), the donee must include the value of the item on his or her taxable income. As such, IRC $\$ 2512$ explains the gift tax is a tax imposed on the donor, rather than the donee, on the fair market value of the taxable gift less any available deductions and exclusions. The gift tax is based upon the estate tax brackets with the highest rate currently at 40\%. Nevertheless, the JCT (2015) notes that since individuals have the lifetime exemption, any gift in excess of the lifetime exemption are generally subject to the gift tax at the highest marginal $40 \%$ rate.

Along with the per donee and lifetime exclusions, IRC $\$ 2503$ provides other exclusions for the type of gift provided. For example, an unlimited exclusion is available to individuals providing direct payments to a donee's educational institution for tuition expenses, to a donee's medical provider for health care expenses, or to a charitable organization (IRC §2503). Additionally, IRC §2523 notes gifts provided to one's spouse are exempt from the gift tax. Lanza (2014) also explained spouses can each provide up to the annual per donee threshold to the same recipient without incurring the gift tax. This process is known as gift splitting, where a gift is assumed to be made one-half by the individual and the other by the spouse, doubling the annual per donee exclusion (IRS, 2016a). Nevertheless, if a person receives a "gift" through part of a promotion (e.g., a lottery or contest of chance), the "gift" is considered income for the donee as the donor is getting something in return (e.g., self-promotion) in exchange for the gift-giving opportunity (IRC §74; IRS, 2016b).

\section{Defining "Gift"}

Because of the potential ambiguity behind the term "gift," lawmakers have never proposed legislation that would provide definitive guidance (Battista, 2015; Dietz, 2014; Kahn \& Kahn, 2003; Schmalbeck, 2010). Instead, the Supreme Court offered the standard behind the term in Commissioner v. Duberstein (1960). The case involved a taxpayer, who was the president of an iron and steel company, receiving a Cadillac as a present from an executive of a separate business after 
the taxpayer provided the executive with valuable customer information. The taxpayer initially declined the gesture but eventually accepted the car while protesting he did not want compensation for the information. He did not include the value of the Cadillac in his gross income, deeming it a gift. Conversely, the IRS argued the car qualified as income to the taxpayer and asserted a deficiency against him after he failed to pay taxes on the car (Commissioner v. Duberstein, 1960). The IRS became aware of this item on the other business's tax return, which deducted the vehicle as a business expense.

During the case, the IRS advocated the Supreme Court adopt a test where "gifts" would be determined by the context in which they are given (Dietz, 2014). Specifically, transfers made for business reasons, such as payments made by an employer to an employee, would not be considered gifts while transfers made for personal reasons could qualify. The Court rejected this proposed test, arguing these guidelines are more akin to maxims of experience opposed to principles of law and "whether a transfer amounts to a 'gift' is one that must be reached on consideration of all the factors" (Commissioner v. Duberstein, 1960, p. 288). While a test was not adopted, the Court did identify that intent of the payment is important to qualifying it as a gift (Battista, 2015; Kahn \& Kahn, 2003; Schmalbeck, 2010). According to the Court, the most important consideration in determining whether an item qualifies as a gift is whether the donor's intention of item gifting is made out of a detached and disinterested generosity (Commissioner v. Duberstein, 1960, Commissioner v. LoBue, 1956). In other words, Dietz (2014) explained a gift is a transfer of goods or services made out of admiration, respect, charity, or other similar emotions. In Duberstein, the Court found the Cadillac was not a gift to the taxpayer, as the motives behind the car were not "disinterested;" it was given as compensation for customer information. Still, the Courts established each gift is determined on a case-by-case basis, requiring a nuanced, multifaceted analysis before reaching a conclusion, especially when considering a detached and disinterested generosity (Battista, 2015). This rationale explains why the Courts have difficulty applying this definition in certain cases (Dietz, 2014).

For example, in Goodwin v. United States (1995), a popular pastor in Des Moines, Iowa, who grew his congregation from 25 members to 400 , was routinely provided with "gifts" from his congregation at Christmas and three "special occasion" days each year. Initially, the congregation would provide items such as furniture and works of art but later began providing cash. The congregation began to develop a regular procedure where the associate pastor would announce the gift-giving occasion approximately two weeks before each special occasion day when the pastor was not present (Goodwin v. United States, 1995). Members would then give envelopes with cash to preserve anonymity to the associate pastor or church deacon, and the church did not keep records of the donors or amounts given. The pastor did not include these special occasion gifts as taxable income, and the IRS assessed deficiencies for three years based upon the estimated and unreported special occasion gifts (Goodwin v. United States, 1995).

Dietz (2014) explained the church had no written policy or requirement that anyone give a gift, nor were members required to give in any amount. Members also argued the gifts were given out of "love, respect, admiration and like impulses and [were] not given out of any sense of obligation or any sense of fear that [Reverend Goodwin] [would] leave their parish if he [was] not compensated 
beyond his yearly salary" (Goodwin v. United States, 1995, pp. 149-150). While the intent of the congregation appears to meet the detached and disinterested generosity element in Duberstein, the Courts deemed the cash collected during the special occasion days were not gifts since the contributions were made by the congregation as a whole as opposed to individual members through a highly structured and routinized program (Goodwin v. United States, 1995). Furthermore, the Court argued the congregation was aware that without the use of these special occasion days to provide supplemental funding, the Church would be unlikely to retain the services of a popular and successful minister at relatively low compensation. As such, the Courts concluded the payments did not qualify as gifts for tax purposes (Goodwin v. United States, 1995).

Similarly, in Olk v. United States (1976), the court addressed whether money received by craps dealers in Las Vegas casinos constituted taxable income or gifts. Known as "tokes," individuals participating in a craps game would give money to dealers or place bets for them (Dietz, 2014). At the end of a dealer's shift, the tokes would be split among the dealers, with each dealer getting a share of the total regardless of whether the dealer was working when tokes were received (Kahn \& Kahn, 2003). Casino management permitted this practice but did not encourage it, as the tokes represented money that could not be won by the casino. The dealers did not report the tokes as income, classifying them as gifts, and the IRS disagreed (Olkv. United States, 1976).

Parallel to Goodwin, the players had no obligation to give the dealer tokes, and only $10 \%$ of all players gave tokes to the dealers (Dietz, 2014). As such, the lower court ruled in favor of the dealers, noting "tokes are given to dealers as a result of impulsive generosity or superstition on the part of players, and not as a form of compensation for services" (Olk v. United States, 1975, p. 1114). Furthermore, due to the low number of patrons providing tokes, the lower court established a detached and disinterested generosity. The Ninth Circuit court disagreed with the lower court ruling, reversing the decision. Specifically, the appellant court ruled tokes did not qualify as gifts as "tribute to the gods of fortune which it is hoped will be returned bounteously soon can only be described as an "involved and intensely interested act"' (Olk v. United States, 1976, p. 879). The court stated that certain elements such as the pooling of tokes, regularity of receipt, and the amounts received indicate a reasonable and prudent person would regard the receipt of tokes as compensation. Dietz (2014) agreed with this assessment since a player in a game of chance would give tokes if it changed his or her luck but acknowledged the court in Olk did not help taxpayers determine what is or is not a gift.

These two cases highlight the inconsistency in interpreting the Supreme Court's decision in Duberstein. Specifically, the Supreme Court acknowledged a gift can be determined by the intent of the donor. However, the courts in Goodwin and Olk based their decisions on the factual circumstances surrounding the transaction such as payment regularity or established payment procedures (Battista, 2015; Kahn \& Kahn, 2003; Schmalbeck, 2010). Additionally, the courts also clarify an indirect benefit to the donor may be sufficient to distinguish gifts and income, regardless of if the indirect benefit does not flow from the donee. As such, Dietz (2014) explained that one must look at both the donor's intent and the circumstances surrounding the transactions. 


\section{Application of Gift Tax}

For all individuals subject to the gift tax, they are required to complete Form 709 (IRS, 2016c), which is used to report gifts over the per donee exemption and calculate the amount due in taxes. Individuals must complete this form if they gave a gift totaling more than the per donee exemption, even if not paying a gift tax, in order to maintain records of an individual's lifetime exemption. The following examples involving Tom Brady, Derek Jeter, and Kobe Bryant as well as a hypothetical NFL undrafted free agent coming out of college provide detail to the intent of the actions in question and potential application of the gift tax.

\section{The Brady Scenario}

Brady received a 2015 Chevy Colorado as a prize for his MVP performance in Super Bowl XLIX. As the car is considered a prize, it is taxable under IRC $\$ 74$ and must be included in Brady's gross income. Brady would report the fair market value of the vehicle $(\$ 34,000)$ as taxable income (Ellis, 2015). According to Yates (2013), Brady signed a contract in 2013 that stated his annual salary in 2015 would be $\$ 8$ million, meaning it is reasonable to assume Brady is in the highest income tax bracket $(39.6 \%$ in 2015; Rev. Proc. 2014-61, 2014). Thus, Brady would pay approximately $\$ 13,500(\$ 34,000 \times 39.6 \%)$ in federal income taxes for the prize.

Additionally, Brady provided Butler with the vehicle as a present. At face value, it appears the vehicle was given as a reward for Butler's effort with a detached and disinterested generosity from Brady. Because a detached and disinterested generosity can be established, Butler would not have to include the gift as income on his personal tax return. Instead, Brady will need to complete a gift tax return after gifting the vehicle. Since the truck was given in 2015 , Brady's annual per donee exclusion was $\$ 14,000$ and the taxable portion of the vehicle was $\$ 20,000$. Ellis (2015) also suggested Brady has likely provided over his lifetime gift exclusion (\$5.25 million in 2015; Rev. Proc. 2014-61, 2014) due to his high salary. As such, Brady would exceed his lifetime exclusion and would be assessed a gift tax on the taxable portion of the vehicle's value at the highest rate of $40 \%$. Thus, Brady would pay an additional $\$ 8,000(\$ 20,000 \times 40 \%)$ for gifting the vehicle to Butler, making his total taxes owed on the car $\$ 21,500$.

\section{The Jeter Scenario}

Jeter received gifts valued at approximately \$33,000 (“Jeter May Owe," 2014). As a donee, one would not have to pay taxes on gifts received. Conversely, Wood (2014) contended the gifts provided to Jeter may not have been made from a detached or disinterested generosity. Instead, he suggested the gifts provided by the MLB players and franchises possessed more of a business context, specifically marketing, rather than a charitable act or selfless gesture. For example, the Boston Red Sox and the Toronto Blue Jays held pregame ceremonies in honor of Jeter to provide him with gifts, promoting the event and selling tickets to fans (Bowers, 2014; Griffin, 2014). Both Burke and Friel (2013) and Dietz (2014) noted gifts exchanged within a commercial or business setting may not qualify for the $\$ 102$ 
exemption depending upon the scenario in which the gifts were exchanged.

These giveaways could be constituted as marketing practices that lack a detached and disinterested generosity, meaning the gifts are classified as taxable income. This reasoning would not require a gift tax consideration, as Jeter would only need to pay taxes on income earned. Like Brady, Jeter's high salary would place him in the highest federal tax bracket (39.6\%), and he would pay over $\$ 13,000(\$ 33,000 \times 39.6 \%)$ in federal income taxes. Conversely, Wood (2014) argued Jeter could have avoided the gift tax if the items were provided directly to his non-profit organization, Turn 2 Foundation, as opposed to himself. This type of transaction would treat the items as charitable donations (e.g., from the teams to the foundation) to Jeter's non-profit firm as opposed to taxable income, shielding Jeter from the $\$ 13,000$ tax liability. In other words, teams would be making a charitable donation to Turn 2 Foundation, creating a deductible business expense for the team and shielding Jeter from any personal income taxation issues, as the item would not be considered income.

\section{The Bryant Scenario}

In comparison to Jeter, Bryant received a multitude of gifts from many National Basketball Association (NBA) players and team executives during his final season in 2016 (Holmes, 2016). Specifically, at a private dinner party at the Parcae Restaurant in Toronto, Canada, several NBA stars (e.g., Carmelo Anthony, Chris Paul, Dwayne Wade) provided Bryant with gifts like a bottle of wine, a walking cane, a subscription to Netflix, a robe embroidered with Bryant's nickname of Black Mamba in gold, and underwear from Wade's Wade X Naked line (Greer, 2016). While most of these gestures were done as jokes among friends, the biggest gift that Bryant received was from Michael Jordan during Bryant's final NBA All-Star Game. Jordan and his shoe brand presented Bryant with every pair of Jordan line shoes since its inception in 1984 ("Michael Jordan Gives Full Set," 2016). According to Bohn (2016), Bryant was absolutely flattered by the gesture because "the set included multiple pairs of shoes that Bryant eagerly wanted to acquire as a youngster" (para. 4). The shoes gifted to Bryant were all in white, and the Jordan Brand chose to auction a second set that were in all black (Bohn, 2016). This second set was sold for $\$ 240,100$, with the proceeds split between the Jordan Wings Initiative and the Kobe and Vanessa Bryant Family Foundation ("Jordan Brand Pays Tribute," 2016).

Similar to Butler, the person receiving the gift would not be responsible for paying taxes on a gift given to him. Yet, the party providing the gift could be subject to gift taxes. In the case of the Air Jordan package, it was distributed by the Jordan Brand, a corporation. According to IRC $\S 102$, only individuals are required to complete a gift tax return. However, if a trust, estate, partnership, or corporation makes a gift, the individual beneficiaries, stockholders, or partners can be considered donors and could be liable for the gift tax. While it is likely the gift tax would be split among shareholders at the Jordan Brand, one can assume the gift was the decision of Michael Jordan exclusively, making Jordan responsible for paying the gift tax. According to Forbes, Jordan's current net worth is over $\$ 1.31$ billion, which places him in the highest tax bracket in the 
United States. Assuming like Brady, Jordan has exceeded his lifetime gift tax exclusion (\$5.450 million in 2016; Rev. Proc. 2016-55, 2016), he would have to pay approximately $\$ 90,000(\$ 226,100 \times 40 \%)$ in gift taxes.

\section{The Undrafted Player Scenario}

After spending three years at the University of Kentucky, running back John Doe decided to forego his senior year and declare for the 2017 NFL Draft. Despite being cautioned that the earliest he may be drafted would be the 5 th round, Doe decided to enter the draft in order to generate income to provide more for his 3 -year-old daughter. Although Doe scored well on several physical tests at the NFL Combine, he ran a sub-par 40-yard dash, hurting his overall draft stock. As such, all 32 teams opted to pass on selecting Doe for all seven rounds. Following the draft, the Cincinnati Bengals contacted Doe's agent and informed him the Bengals wanted to sign Doe as an undrafted free agent (UFDA). Doe was ecstatic and quickly agreed to terms on a three-year, $\$ 1.460$ million contract with a $\$ 20,000$ signing bonus, meaning Doe would earn $\$ 465,000$ in the first year, $\$ 480,000$ in the second year, and $\$ 495,000$ in the third year along with a $\$ 20,000$ signing bonus (Ginnitti, 2017). Upon signing the deal, Doe celebrated by purchasing a brand new vehicle for his mother, a 2017 Toyota 4Runner, as a gift for her hard work to get him to this point. Doe did not barter with the car dealership, opting to purchase the vehicle at the manufacturer's suggested retail price (MSRP) of \$34,210 (“Buyer's Guide: 2017 Toyota,” n.d.).

Doe has never provided a gift with such a high value before, but the vehicle's value will require him to complete a Form 709 for the gift and estate tax, as it exceeds his annual exemption of $\$ 14,000$. Yet, Doe would not be subject to the gift tax, as he has not used any of his lifetime exemption (\$5.490 million in 2017; Rev. Proc. 2016-55, 2016). Still, Doe will need to complete Form 709 to record the amount of lifetime exemption utilized for this gift. In this case, Doe would reduce his lifetime exemption by $\$ 20,210$ (\$34,210 - \$14,000), leaving approximately $\$ 5.47$ million exempt from the estate tax.

\section{Conclusion}

While many criticize the federal estate tax, including President Donald J. Trump (Baron, 2017), the gift tax and its relation to the estate tax does not appear to warrant any legislative changes. Conversely, it is important for one to understand the application of the gift tax and its potential implications toward one's estate as assets are passed down. While most people should not have to worry about paying the gift tax, it is still important to identify the thresholds that could initiate the tax in case they consider gifting any item exceeding the annual per donee and lifetime exemptions, even if the gifting event occurs once. Should the situation occur, an individual will need to report to the IRS the value of the gift to determine his or her lifetime exemption for estate tax purposes.

In comparison, professional athletes should possess higher considerations for the types of gifts they provide as it relates to their retirement and estate planning. Many professional athletes show tendencies to give gifts to family members and fellow teammates (Barron, 2015; Kelly, 2015). While there is nothing wrong with 
the charitable act of giving gifts, professional athletes may rapidly exceed their annual per donee exemption and reduce their overall estate lifetime exemption. Should this situation occur, the athlete would leave a significantly higher tax burden for the athlete's decedents upon his or her death through the estate tax (IRC §2001).

For example, Tom Brady and his wife Gisele Bundchen's net worth is $\$ 540$ million, which is comprised of their annual salaries, endorsement deals, and the fair market value of any property the couple own (Ruhlin, 2017). Upon their deaths, the couple's combined property would likely be passed to their children, who would have to pay taxes on the property's value. Because of the high dollar amount, it is likely the decedents would pay taxes within the highest bracket (39.6\% in 2017; Rev. Proc. 2016-55, 2016). If Brady and his wife did not provide any gifts, they would be able to combine their lifetime exemptions to shield their children from federal estate taxes up to the lifetime threshold ( $\$ 10.98$ million in 2017, Rev. Proc. 2016-55, 2016). However, any provided gifts exceeding the annual per donee and lifetime exemptions would create a higher tax burden for the decedents. In the Brady example, the decedents would be liable for an additional $\$ 4.35$ million ( $\$ 10.98$ million $\times 39.6 \%$ ) in estate taxes if Brady and Bundchen exceeded their combined lifetime exemption. As such, it would be advantageous for all athletes to manage the amount they provide in terms of gifts to make sure the present day gift does not turn into a future tax burden.

Conversely, individuals receiving gifts are usually not taxed on the item's value unless there is not a detached and disinterested generosity associated with the gift giving process. In the case of Derek Jeter, some of the gifts provided to him during his final playing year were used as marketing tools by the organization to promote a special day and sell tickets. In other words, the clubs offering presents were "paying" for Jeter's services as a retiring athlete to increase ticket sales for those games. As such, the items Jeter received are considered payment for those services and should be taxed as income (IRC §61(a)). Again, there is nothing wrong with this practice, as it is fair to honor a retiring athlete with a stellar career like Jeter's. Instead, teams conducting this practice should carefully detail the events planned for these occasions, including the actual use of the items provided to the athlete. The organization would also be wise to provide any and all gifts to a charity or foundation of the athlete's choice. This act would serve as a deductible business expense for the firm as opposed to taxable income for the athlete.

The gift tax appears to be a complex form of taxation that one can easily confuse since it appears to penalize the charitable act of providing gifts to individuals. Further, the tax itself could caution companies and individuals from providing charitable gestures to worthy individuals to celebrate their achievements. Despite this apparent suggestion, the gift tax was not meant to discriminate against gift giving but rather limit past abuses surrounding estate planning (Joulfaian, 1998; Luckey, 2003). Thus, professional athletes should inform their agents or financial planners of their intent to provide lavish gifts to others. It is up to the agent and financial planner to advise the athlete on the procedures to report the gift amount to the IRS as well as the implications for estate taxes should the athlete not have depleted his or her entire lifetime exemption, as well as potentially creating a substantial tax burden for his or her descendants. Thus, 
it would be wise for all athletes to work with their financial planners and/or agents to carefully design a retirement plan that cautions against providing gifts exceeding the per donee and lifetime thresholds. This plan should not restrict the ability to provide an individual a gift, but rather limit the value of the gift to save decedents from any future tax burdens.

\section{References}

Baron, N. (2017, May 1). Trump's tax plan a new death tax for the middle class? The Hill. Retrieved from http://thehill.com/blogs/pundits-blog/economy-budget/331434-trumps-tax-plan-anew-death-tax-for-the-middle-class

Barron, T. (2015, May 10). Hay mama, five of our favorite examples of athletes giving back to their moms. ESPN. Retrieved from http://www.espn.com/espn/story/_page/instantawesome-mothersday-12843884/athletes-giving-gifts-their-moms

Battista, P. (2015). The taxation of crowdfunding: Income tax uncertainties and a safe harbor test to claim gift tax exclusion. The University of Kansas Law Review, 64, 143-186.

Bohn, M. (2016, February 15). Kobe Bryant gets all Air Jordans as retirement gift. USA Today. Retrieved from http://www.usatoday.com/story/sports/nba/lakers/2016/02/14/kobe-bryant-michael-jordan-air-jordans-nba-all-star-game/80378114/

Bowers, R. (2014, September 28). Derek Jeter, Yankees thrilled with Fenway Park sendoff. Boston Globe. Retrieved from https://www.bostonglobe.com/sports/2014/09/28/red-sox-show-their-respect-before-derek-jeter-final-game/veVXeaieCELfVCm4IJfM2I/story.html

Brewer, B. (1993). Self-identity and specific vulnerability to depressed mood. Journal of Personality, 343-364. https://doi.org/10.1111/j.1467-6494.1993.tb00284.X

Brewer, B., Van Raalte, J., \& Linder, D. (1993). Athletic identity: Hercules' muscles or Achilles heel? International Journal of Sport Psychology, 24, 237-254. https://doi.org/10.1037/t15488000

Brisbee, G. (2014, February 12). Inside Derek Jeter's retirement gift basket. SBNation. Retrieved from http://www.sbnation.com/mlb/2014/2/12/5406124/derek-jeter-retirement-gift-basket

Bromley v. McCaughn, 280 U.S. 124 (1929).

Burke, J., \& Friel, M. (2013). Understanding federal income taxation (4th ed.). Los Angeles, CA: LexisNexis.

Buyer's guide: 2017 Toyota 4Runner. (n.d.). MotorTrend. Retrieved from http://www.motortrend. com/cars/toyota/4runner/2017/

Celani, A. (2014, September 29). 8 awful parting gifts that teams gave Derek Jeter. CBS Boston. Retrieved from http://boston.cbslocal.com/2014/09/29/8-awful-parting-gifts-that-teams-gave$\underline{\text { derek-jeter/ }}$

Commissioner of Internal Revenue v. Duberstein et ux., 376 U.S. 278 (1960).

Commissioner of Internal Revenue v. LoBue, 351 U.S. 243 (1956).

DaSilva, C. (2017, February 7). Tom Brady can't give Super Bowl MVP truck to James White for one obvious reason. FOX Sports. Retrieved from http://www.foxsports.com/nfl/story/new-england-patriots-tom-brady-super-bowl-mvp-truck-james-white-020717

DeCola, P. (2016). Jeff Gordon's retirement gifts: Where are they now? NASCAR. Retrieved from http://www.nascar.com/en_us/news-media/blogs/inside-groove/2016/7/29/jeff-gordon-retirement-gifts-going-to-good-use.html

Dietz, E. (2014). The tax code's crowdfunding dilemma; The temptation of Kickstarter creators to use the gift exclusion under Section 102(a). Hamline Law Review, 37, 293-310. 
Ellis, R. (2015, February 4). IRS is coming after Tom Brady's Super Bowl MVP truck. Forbes. Retrieved from http:/www.forbes.com/sites/ryanellis/2015/02/04/irs-to-steal-tom-bradys-super-bowl-mvp-truck/

Gale, W., \& Slemrod, J. (2001). Rethinking the estate and gift tax: Overview (Working Paper 8205). Cambridge, MA: National Bureau of Economic Research. Retrieved from http://www. nber.org/papers/w8205.pdf

Ginnitti, M. (2017, January 28). NFL minimum salaries for 2017. Spotrac. Retrieved from https:// www.spotrac.com/blog/nfl-minimum-salaries-for-2017/

Goodwin v. United States of America, 67 F.3d 149 (8th Cir. 1995).

Greer, C. (2016). NBA stars shower Kobe Bryant with retirement gifts. Page Six. Retrieved from http://pagesix.com/2016/02/21/nba-stars-shower-kobe-bryant-with-retirement-gifts/

Griffin, R. (2014, August 31). Derek Jeter's Toronto sendoff includes Banff getaway. The Star. Retrieved from https://www.thestar.com/sports/bluejays/2014/08/31/derek_jeters toronto_sendoff includes banff getaway.html

Hanzus, D. (2016, March 7). Peyton Manning announces retirement from NFL. National Football League. Retrieved from http:/www.nfl.com/news/story/0ap3000000641930/article/peyton-manning-announces-retirement-from-nfl

Holmes, B. (2016, April 10). Toasting the Mamba: All-Star trio honors Kobe Bryant. ESPN. Retrieved from http://www.espn.com/nba/story/_id/15175760/kobe-bryant-most-memorable-re$\underline{\text { tirement-gift }}$

Internal Revenue Code of 1986, 26 U.S.C. $\$ 1$.

Internal Revenue Code of 1986, 26 U.S.C. §61(a).

Internal Revenue Code of 1986, 26 U.S.C. $\$ 74$.

Internal Revenue Code of 1986, 26 U.S.C. $\$ 102$.

Internal Revenue Code of 1986, 26 U.S.C. \$132(a).

Internal Revenue Code of 1986, 26 U.S.C. \$132(d).

Internal Revenue Code of 1986, 26 U.S.C. \$132(e).

Internal Revenue Code of 1986, 26 U.S.C. $\$ 170(c)$.

Internal Revenue Code of 1986, 26 U.S.C. $\$ 2001$.

Internal Revenue Code of 1986, 26 U.S.C. $\$ 2503$.

Internal Revenue Code of 1986, 26 U.S.C. $\$ 2512$.

Internal Revenue Code of 1986, 26 U.S.C. $\$ 2523$.

Internal Revenue Service. (2014). Publication 5137: Fringe benefit guide. Washington, D.C.: Author. Retrieved from https://www.irs.gov/pub/irs-pdf/p5137.pdf

Internal Revenue Service. (2016a). Publication 559: Survivors, executors, and administrators. Washington, D.C.: Author. Retrieved from https://www.irs.gov/pub/irs-pdf/p559.pdf

Internal Revenue Service. (2016b). Publication 525: Taxable and nontaxable income. Washington, D.C.: Author. Retrieved from https://www.irs.gov/pub/irs-pdf/p525.pdf

Internal Revenue Service. (2016c). 2016 instructions for Form 709 - United States gift (and generation-skipping transfer) tax return. Washington, D.C.: Author. Retrieved from https://www.irs. gov/pub/irs-pdf/i709.pdf

Jeter may owe $\$ 16,000$ in taxes on farewell gifts. (2014, September 23). The Chicago Tribune. Retrieved from http:/www.chicagotribune.com/sports/breaking/chi-jeter-may-owe-16000-intaxes-on-farewell-gifts-20140923-story.html?track=rss 
Joint Committee on Taxation. (2015). History, present law, and analysis of the federal wealth transfer tax system (JCX-52-15). Washington, D.C.: Author.

Jordan brand pays tribute to Kobe Bryant. (2016, February 12). Nike. Retrieved from http://news. nike.com/news/jordan-kobe-bryant

Joulfaian, D. (1998). The federal estate and gift tax: Description, profile of taxpayers, and economic consequences (OTA Paper 80). Washington, D.C.: Department of the Treasury.

Kahn, D., \& Kahn, J. (2003). "Gifts, gafts, and gefts" - The income tax definition and treatment of private and charitable "gifts" and a principled policy justification for the exclusion of gifts on income. Notre Dame Law Review, 78, 441-526.

Kelly, R. (2015, June 16). 10 best gifts athletes gave their teammates. CBS Local Sports. Retrieved from http://sports.cbslocal.com/2015/06/16/10-best-gifts-athletes-gave-their-teammates/

Kerr, G., \& Dacyshyn, A. (2000). Retirement experiences of gymnasts. Journal of Applied Sport Psychology, 12, 115-133. https://doi.org/10.1080/10413200008404218

Kramer, S., \& Previts, G. (2015). Ivar Kreuger and IMCO: A case of taxation of fictitious income. The International Journal of Accounting, 50, 300-315. https://doi.org/10.1016/j. intacc.2015.07.004

Lanza, E. (2014). The federal estate, gift, and generation-skipping transfer taxes (CRS Report 95-416). Washington, D.C.: Congressional Research Service. Retrieved from https://fas.org/sgp/ crs/misc/95-416.pdf

Lally, P. (2007). Identity and athletic retirement: A prospective study. Psychology of Sport and Exercise, 8, 85-99. https://doi.org/10.1016/j.psychsport.2006.03.003

Laura, R. (2013, January 26). Saying goodbye to retirement traditions. Forbes. Retrieved from https://www.forbes.com/sites/robertlaura/2013/01/26/saying-goodbye-to-retirement-traditions/\#5c6e147d66a

Luckey, J. (2003). A history of federal estate, gift, and generation-skipping taxes (CRS Report 95444). Washington, D.C.: Congressional Research Service. Retrieved from https://www.naepc. org/journal/issue01f.pdf

Matthews, W. (2014, September 26). Derek Jeter hero in Bronx finale. ESPN. Retrieved from http://espn.go.com/new-york/mlb/story//id/11589333/derek-jeter-plays-final-home-game-newyork-yankees

Michael Jordan gives full set of Air Jordans to Kobe Bryant. (2016, February 14). ESPN. Retrieved from http://www.espn.com/nba/story//id/14770507/michael-jordan-gifts-set-air-jordans-losangeles-lakers-star-kobe-bryant

Olk v. United States of America, 388 F.Supp. 1108 (Nev. 1975).

Olk v. United States of America, 536 F.2d 876 (9th Cir. 1976).

Patra, K. (2015, February 1). Tom Brady wins Super Bowl XLIX MVP award. National Football League. Retrieved from http://www.nfl.com/news/story/0ap3000000467491/article/tom-bradywins-super-bowl-xlix-mvp-award

Private Letter Ruling 200108042 (2001, February 23).

Revenue Procedure 2013-35, 2013-47 C.B. 537.

Revenue Procedure 2014-61, 2014-47 C.B. 860.

Revenue Procedure 2016-55, 2016-45 C.B. 707.

Rose, B. (2014, September 24). Derek Jeter owes $\$ 16 \mathrm{k}$ in taxes due to farewell gifts. Fansided. Retrieved from http://fansided.com/2014/09/23/derek-jeter-owes-16k-taxes-due-farewell-gifts /\#respond 
Ruhlin, W. (2017, February 6). Here's how much Tom Brady and Gisele Bundchen are worth. AOL Finance. Retrieved from https://www.aol.com/article/finance/2017/02/06/heres-how-much-tombrady-and-gisele-bundchen-are-worth/21708210/

Schechter, L. (2015, February 3). Brady to give MVP truck to Butler. ESPN. Retrieved from http:// espn.go.com/boston/nfl/story/_id/12272310/tom-brady-new-england-patriots-plans-give-mvptruck-malcolm-butler

Schmalbeck, R. (2010). Gifts and the income tax - An enduring puzzle. Law and Contemporary Problems, 73, 63-93.

Sorokanich, R. (2015, February 3). Tom Brady is giving his Super Bowl MVP Chevy Colorado to game-clinching teammate Malcolm Butler. Car and Driver. Retrieved from http://blog. caranddriver.com/tom-bradys-giving-his-super-bowl-mvp-chevy-colorado-to-game-winnermalcolm-butler/

Sparkes, A. (1998). Athletic identity: An Achilles' heel to the survival of self. Qualitative Health Research, 8, 644-664. https://doi.org/10.1177/104973239800800506

Spencer, R. (2015, November 23). Retiring Jeff Gordon bows out of NASCAR Cup with class showing at Homestead. Autoweek. Retrieved from http://autoweek.com/article/nascar-sprintcup/retiring-jeff-gordon-bows-out-nascar-cup-classy-showing-homestead

Wood, R. (2014, September 24). Derek Jeter's big tax bill on 'gifts' that really aren't gifts. Forbes. Retrieved http://www.forbes.com/sites/robertwood/2014/09/24/derek-jeters-big-tax-bill-ongifts-that-really-arent-gifts/

Yates, F. (2013, February 26). Details of Tom Brady's new deal. ESPN. Retrieved from http://www. espn.com/blog/boston/new-england-patriots/post//id/4740303/details-of-tom-bradys-new-deal

Zumwalt, W. (2014, October 8). Derek Jeter should pay taxes on his retirement 'gifts.' EndZoneRealty. Retrieved from http://endzonerealty.com/derek-jeter-tax-retirement-gifts/14361/ 